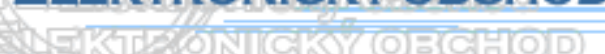

\title{
PROCESNÝ MODEL V SUBDODÁVATELSKEJ FIRME V TELEKOMUNIKÁCIÁCH
}

\author{
Tatiana Čorejová ${ }^{1}-$ Jozef Strigáć $^{2}$
}

\section{Úvod}

Vnímanie hl'adiska kvality sa v posledných rokoch dostalo výrazne do popredia a to tak v pohl'ade na kvalitu zo strany zákazníkov, ale aj výrobcov a poskytovatel’ov služieb. Na tejto skutočnosti má zásadný podiel prevaha ponuky nad dopytom. Naplnenie snahy zo strany podnikov, čo najlepšie pretransformovat' požiadavky zákazníkov do vlastností produktov sa stáva limitujúcim faktorom úspešnosti.

S nástupom liberalizácie začali vel'kí telekomunikační operátori vo svojich stratégiách uplatňovat' prístupy orientácie na „core business“, t.j. na poskytovanie telekomunikačných služieb a postupne odčleňovali prípadne ešte odčleňujú ostatné činnosti vrátane stavebných prác. V tejto pozícii volia dodávatel'ský systém vo výstavbe svojej infraštruktúry. Táto strategická orientácia je spojená so zoštíhl'ovaním organizačnej štruktúry a snahou o znižovanie nákladov.

\section{Dodávatel'ské vzt’ahy vo výstavbe v telekomunikáciách}

Dodávatel'ské systémy $\mathrm{v}$ telekomunikačnej výstavbe môžeme charakterizovat' ako množinu účastníkov výstavby a ich vzájomné vzt'ahy (obr. 1). Prijatý systém významne pozitívne, ale aj negatívne vplýva na náklady, kvalitu, trvanie a ekológiu výstavby.

Výstavbou v telekomunikáciách pritom rozumieme súhrn činností všetkých zúčastnených osôb, ktoré sú potrebné na prípravu, zhotovenie a odovzdanie nového alebo rekonštrukciu existujúceho diela investorovi. Účastníkmi výstavby v telekomunikáciách sú všetky právnické a fyzické osoby, ktoré sú priamo zúčastnené alebo dotknuté výstavbou:

- obstarávatel' - získava stavebné dielo do stavu svojho majetku,

- stavebník - obyčajne totožný s obstarávatel’om, zabezpečuje výstavbu, na seba žiada stavebné povolenie,

- investor - býva totožný s obstarávatel'om, financuje výstavbu,

- projektant - zhotovitel' projektovej dokumentácie celej stavby,

- dodávatelia - zhotovitelia časti alebo celej stavby,

- subdodávatelia - zhotovitelia časti stavby alebo celej stavby pre dodávatel'a,

- organizácie pre riadiace a inžinierske činnosti - vybavovanie úradných dokladov, poradenstvo, zhotovovanie odborných štúdií a pod.,

- ostatné zúčastnené osoby, ktorých oprávnené záujmy sú dotknuté predmetnou výstavbou, aj ked' sa jej priamo nezúčastňujú.

\footnotetext{
${ }^{1}$ Prof. Ing. Tatiana Čorejová, PhD., Fakulta prevádzky a ekonomiky dopravy a spojov, Žilinská univerzita v Žiline, e-mail: tatiana.corejova@,fpedas.uniza.sk

${ }^{2}$ Ing. Jozef Strigáč, externý doktorand Fakulta prevádzky a ekonomiky dopravy a spojov, Žilinská univerzita

v Žiline, e-mail: jstrigac@gmail.com
} 
Obstarávatel' môže vykonávat' všetky činnosti pri realizácii stavby sám alebo môže poverit' výkonom určitých prípadne aj všetkých činností iných účastníkov výstavby. Norma STN EN ISO 8402 definuje pojmy:

- dodávatel' - je organizácia, ktorá dodáva výrobok alebo službu, pričom dodávatel’om môže byt' výrobca, distributér, dovozca, montážna alebo obslužná organizácia. Vo vzt'ahu k podniku môže byt' dodávatel' externý alebo interný,

- subdodávatel' - je organizácia dodávajúca výrobok alebo službu dodávatel'ovi.

Vol'ba subdodávatel'ov je závislá najmä od týchto faktorov:

- cena, dostupnost', referencie alebo dobré predošlé obchodné vzt’ahy,

- kvalita,

- informácie o finančnej situácii, manažmente a výrobných pracovníkoch,

- doklad o nezávislom audite alebo certifikácii, atd’..

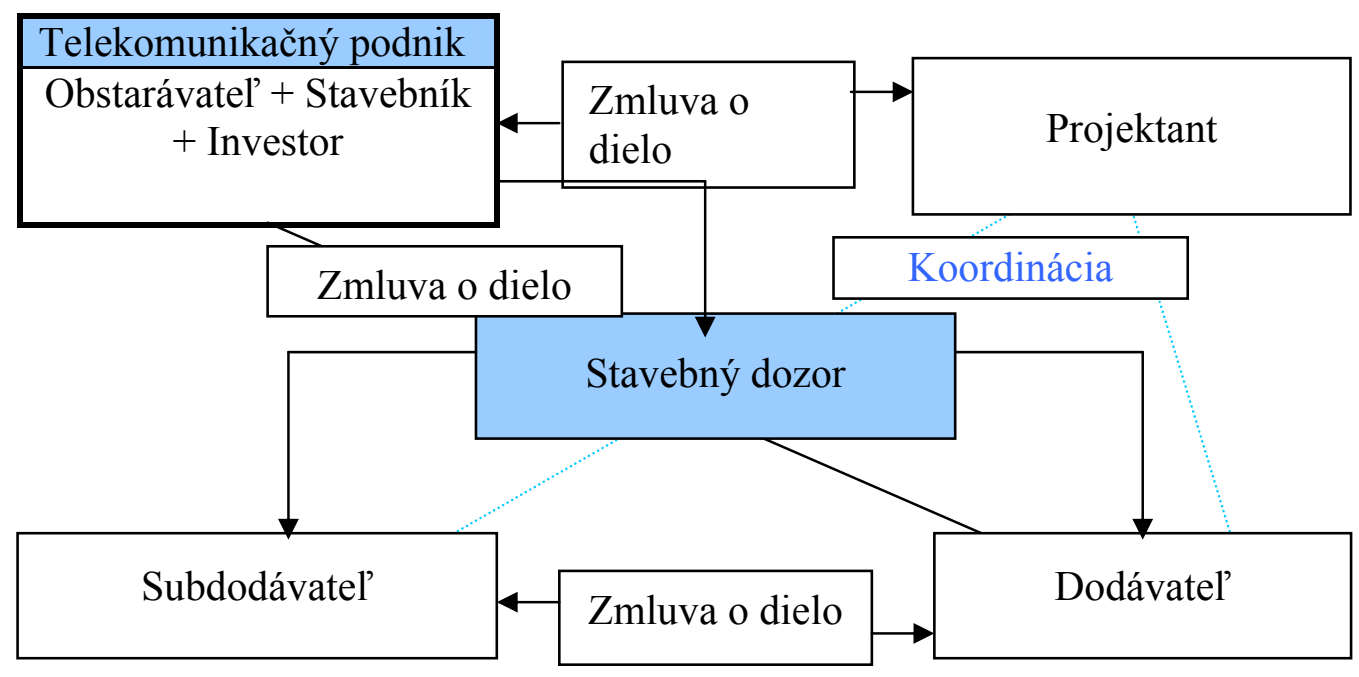

Obr. 1 Systém výstavby v telekomunikáciách

Požiadavky voči subdodávatel'ovi musia byt' jasne definované. Dodávatel' v plnej miere zodpovedá za kvalitu stavby vrátane subdodávok obstarávatel’ovi. Výber vhodných subdodávatel'ov závisí od stanovenia správnych kritérií a ich hodnotenia. V žiadnom prípade nie je možné na výber používat' len jedno kritérium napr. cenu.

\section{Procesy v subdodávatel'ských firmách}

Subdodávatel'ská firma pre telekomunikačné podniky v záujme dosiahnutia ciel'ov definuje celý rad procesov, subprocesov a aktivít, ktoré na seba nadväzujú a vzájomne sa ovplyvňujú. Aby firma mohla realizovat' svoje kl'účové, hodnototvorné procesy (hlavné procesy ) potrebuje podporu celého radu iných procesov. Tab. 1 znázorňuje základné rozdelenie procesov a ich hlavnú náplň v subdodávatel'skej organizácii. Finálne výstupy podporných procesov sú určené pre interných zákazníkov. Na tvorbe pridanej hodnoty pre zákazníka sa tak podiel'a nepriamo. 
Nápln̆ a rozdelenie procesov v subdodávatel’skej firme

Tab. 1

\begin{tabular}{|l|l|}
\hline Procesy & Náplň procesov \\
\hline Hlavné & $\begin{array}{l}\text { realizácia a odovzdanie stavby ( montáž a dodávka metalických a optických } \\
\text { káblov, stavebné a výkopové práce, dodávka a montáž pobočkových } \\
\text { ústrední, oprava údržba telekomunikačných sietí... }) \\
\text { stratégia kvality, } \\
\text { komunikácia so zákazníkmi, } \\
\text { nakupovanie materiálu. }\end{array}$ \\
\hline $\begin{array}{l}\text { Podporné - } \\
\text { riadiace }\end{array}$ & $\begin{array}{l}\text { rozvoj a vzdelávanie personálu, } \\
\text { vedenie účtovníctva, } \\
\text { riadenie dokumentácie a údajov. }\end{array}$ \\
\hline $\begin{array}{l}\text { Podporné - } \\
\text { obslužné }\end{array}$ & $\begin{array}{l}\text { meranie, analýza a zlepšovanie, } \\
\text { bezpečnost'a ochrana zdravia pri práci. }\end{array}$ \\
\hline
\end{tabular}

Pri jednotlivých procesoch je potrebné zmapovat' ich štruktúru, vnútorné zloženie a väzby na vonkajšie okolie, čiže identifikovat' proces. Na rozpracovanie definície konkrétneho procesu v subdodávatel'skej firme je možné použit' techniku modelovania. Proces sa potom zobrazí ako séria subprocesov, ktoré sú na sebe závislé. Zložitý proces sa tým zjednoduší, rozdelí na menšie časti, ktoré možno d'alej rozdel'ovat' na subprocesy nižšej úrovne až na úroveň, ktorá bude vyhovovat' našim aktuálnym potrebám.

Výsledkom modelovania sú jednoduché, zvládnutel'né jednotky, ktoré vzniknú dekompozíciou jednotlivých procesov.

Modelovaním v subdodávatel'skej firme je možné dosiahnut' :

- prehl'adnost', zrozumitel'nost' a jednoznačnost' komunikácie,

- vymedzenie vzt’ahov medzi tzv. internými a externými zákazníkmi subdodávatel'skej organizácie, vzhl'adom na to, že zákazník procesu môže byt' nielen mimo firmy, ale aj vo vnútri firmy ako prijímatel' výstupu procesu predchádzajúceho vykonávatel'a určitej činnosti,

- identifikáciu všetkých vstupov a výstupov,

- vytvorenie modelu formou grafickej metódy - diagramu, ktorá výstižne a stručne ukazuje všetky činnosti, ktoré napĺnajú daný proces a jeho väzby k okoliu, a tým napomáhajú zavádzanie systémov kvality podl'a vybraných prístupov riadenia kvality.

V jednotlivých procesoch subdodávatel'skej firme je potrebné zmapovat' okrem vnútorných činností aj väzby s okolím. K tomuto účelu je možné použit' mapu procesov. Prvá zobrazovacia úroveň zobrazuje štruktúru hlavných a podporných procesov, vzájomné väzby a prepojenie sú symbolicky znázornené na obr. 2.

Definovanie vrcholových procesov je vel'mi dôležité z pohl'adu manažérstva kvality, pretože poskytuje súhrnný prehl'ad požiadaviek zákazníkov a ostatných zainteresovaných subjektov. Na základe požiadaviek sa formulujú ciele a politika kvality. Vzhl'adom na stanovené ciele kvality sa stanovujú meratel’né kritériá, ktoré tvoria základ d’alšieho zlepšovania.

Manažment spoločnosti definuje kritické faktory úspechu, ktoré sú v súlade s podnikatel'ským plánom subdodávatel'skej firmy. Následne určí hierarchiu procesov vo vzt'ahu ku kritickým faktorom úspechu. Najväčšiu prioritu je potrebné pridelit' procesom ktoré vytvárajú hodnotu pre zákazníka a tiež pre firmu. A týmto procesom je potom potrebné venovat' najväčšiu pozornost' zo strany manažmentu, vzhl'adom na následky, ktoré prináša neefektivita procesu s vysokou prioritou v porovnaní s procesom s nižšou prioritou. 


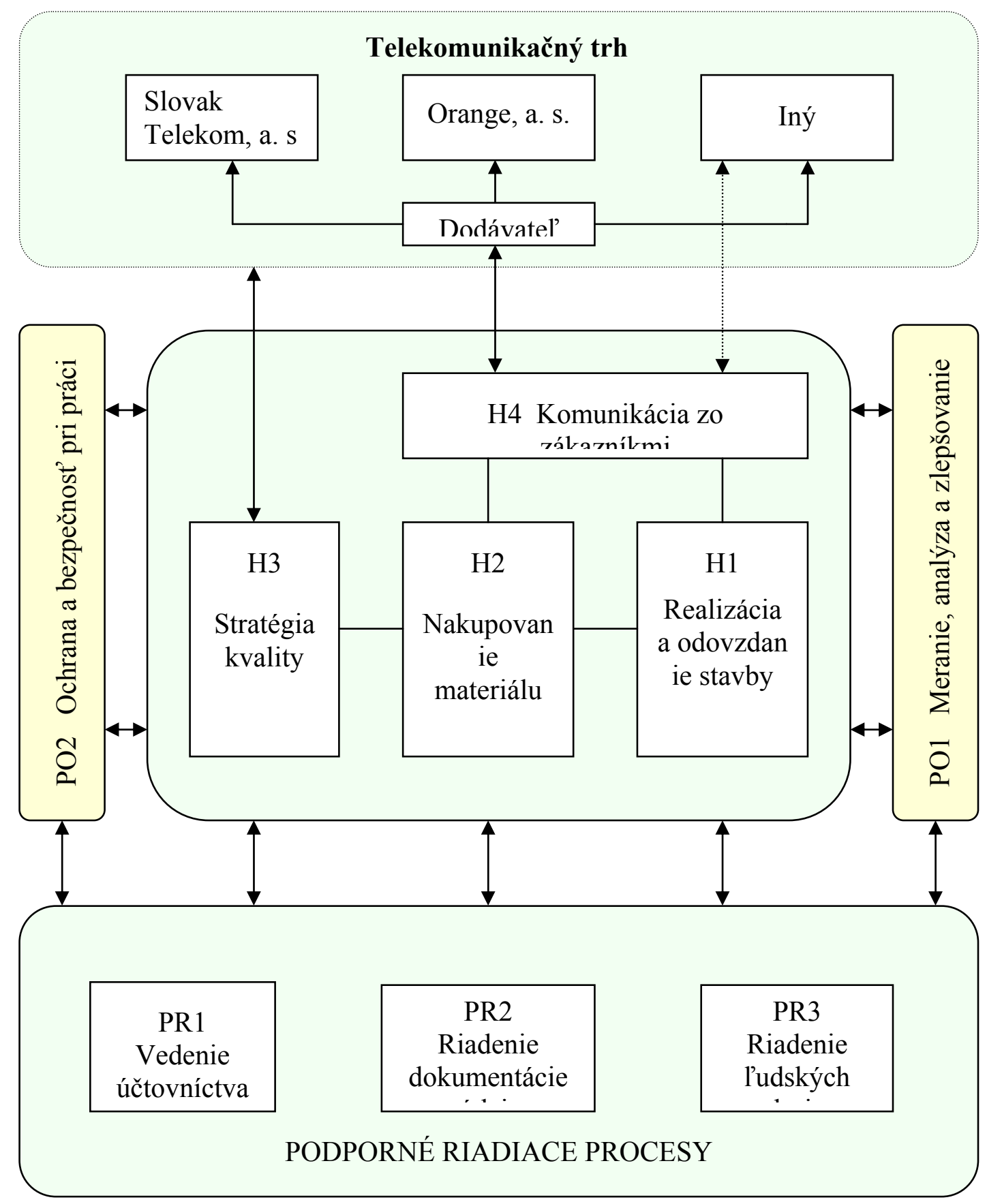

Obr.2 Procesná mapa telekomunikačnej subdodávatel'skej firmy

H1,2,3,4 - hlavné procesy

PO1,2 - podporné obslužné procesy

PR1,2,3 - podporné riadiace procesy 
Ak majú dva procesy rovnakú prioritu, uprednostní sa hlavný proces, ak sú procesy rovnakej kategórie uprednostní sa proces s väčšou hodnotou kritických faktorov úspechu, pričom je možné využit' metódu parciálnej analýzy (tab. 2).

Hierarchizácia procesov v subdodávatel’skej firme

Tab. 2

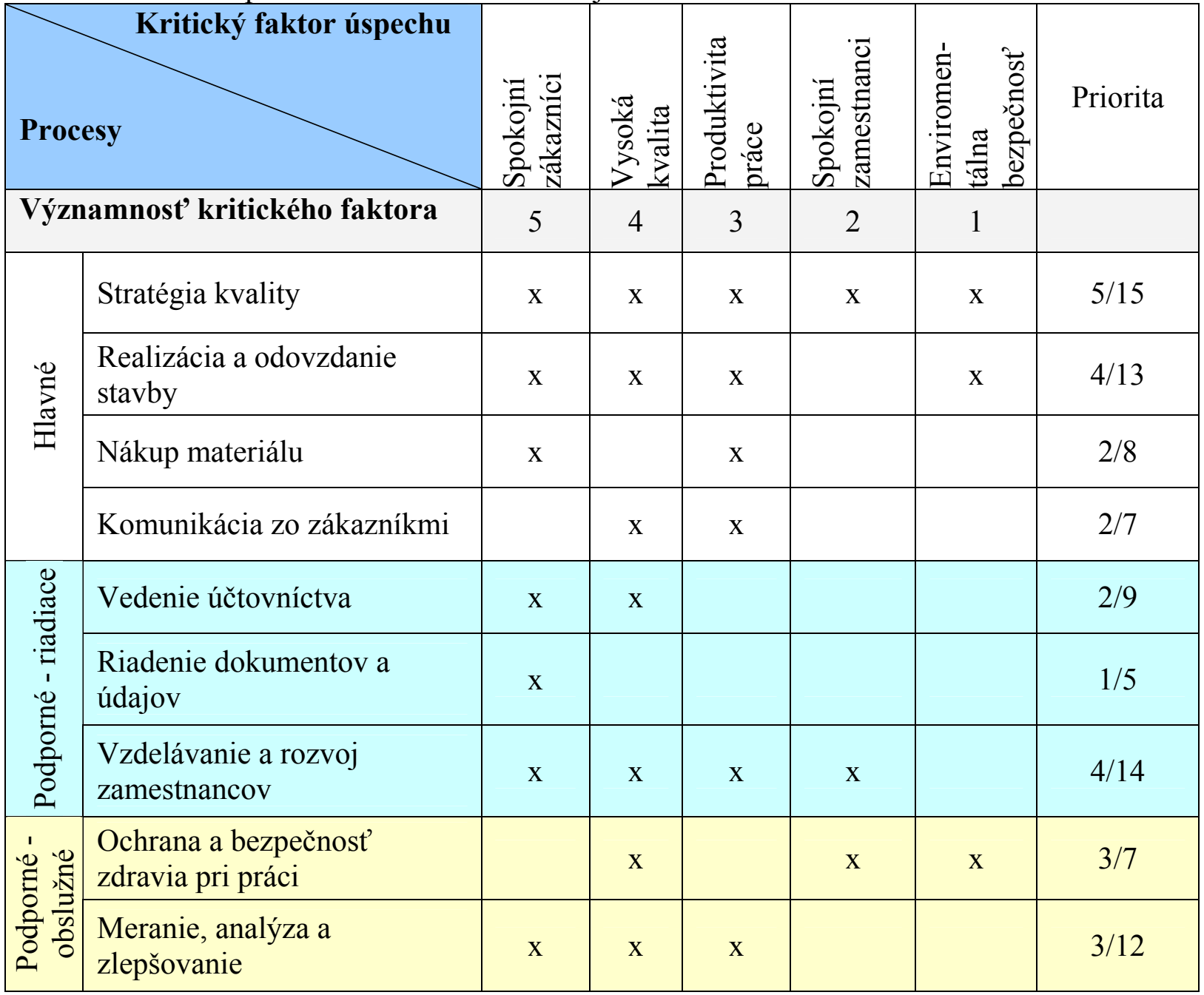

Na stanovenie významnosti kritického faktora úspechu sa použije metóda párového porovnávania. Postup praktického uplatnenia je nasledovný [16] :

1. Do maticovej tabul'ky (tab. 3) sa zapísu kritické faktory úspechu v l'ubovol'nom poradí.

2. Do diagonály matice sa zapíšu poradové čísla porovnávaných kritických faktorov.

3. Postupne sa porovnávajú kritické faktory každý s každým podl'a vybraného kritéria. Poradové číslo faktora, ktorý bol posúdený ako významnejší, medzi dvoma porovnávanými, sa zapíše do príslušného riadka aj stĺpca. V prípade rovnosti páru sa do riadka zapíše číslo prvého porovnávaného, do stĺpca druhého porovnávaného faktora, obidva sa zakrúžkujú, aby sa v záverečnom súčte počítali s polovičnou hodnotou.

4. Nakoniec sa sčíta skóre zrátaním preferencií zist'ovaného kritéria v riadku a výsledok sa zapíše do stípca „Koeficient významnosti““. 
Aplikácia metódy párového porovnávania

Tab. 3

\begin{tabular}{|c|l|c|c|c|c|c|c|c|c|}
\hline P. č. & $\begin{array}{l}\text { Kritický faktor } \\
\text { úspechu }\end{array}$ & $\mathbf{1}$ & $\mathbf{2}$ & $\mathbf{3}$ & $\mathbf{4}$ & $\mathbf{5}$ & $\begin{array}{c}\text { Koeficient } \\
\text { významnosti }\end{array}$ & $\begin{array}{c}\text { Váha v } \\
\mathbf{\%}\end{array}$ & Poradie \\
\hline $\mathbf{1}$ & Produktivita práce & 1 & 2 & 3 & 1 & 1 & 3 & 20,0 & $\mathbf{3}$ \\
\hline $\mathbf{2}$ & $\begin{array}{l}\text { Spokojný } \\
\text { zákazník }\end{array}$ & 2 & 2 & 2 & 2 & 2 & 5 & 33,3 & $\mathbf{1}$ \\
\hline $\mathbf{3}$ & Vysoká kvalita & 3 & 2 & 3 & 3 & 3 & 4 & 26,7 & $\mathbf{2}$ \\
\hline $\mathbf{4}$ & $\begin{array}{l}\text { Environmentálna } \\
\text { bezpečnost' }\end{array}$ & 1 & 2 & 3 & 4 & 5 & 1 & 6,7 & $\mathbf{5}$ \\
\hline $\mathbf{5}$ & $\begin{array}{l}\text { Spokojní } \\
\text { zamestnanci }\end{array}$ & 1 & 2 & 3 & 5 & 5 & 2 & 13,3 & $\mathbf{4}$ \\
\hline
\end{tabular}

Celkový význam jednotlivých kritických faktorov úspechu sa získa ako súčet všetkých vyskytujúcich sa čísel kritického faktora v celom riadku vrátane čísla v diagonále matice. Celková suma takto vzniknutých súčtov výskytov generuje ich poradie významnosti a môže predstavovat' koeficient významnosti v najjednoduchšej podobe.

\section{Záver}

Vytvorenie procesného modelu u všetkých subdodávatel'ov umožní meranie kvality procesov $\mathrm{v}$ týchto subjektoch a hl'adanie kritických článkov $\mathrm{v}$ dodávatel'skom ret’azci stavebných prác $\mathrm{z}$ hl'adiska jednotlivých telekomunikačných operátorov. Zlyhania v niektorých prvkoch dodávatel'ského ret’azca, resp. nekvalita sa totiž prejaví až v procese poskytovania služieb operátorom, čo negatívne vníma zákazník a negatívne sa prajaví vo výsledkoch hospodárenia operátora.

\section{Použitá literatúra:}

[1] DUPAL, A.: Logistická podpora výrobného procesu. Bratislava: Ekonóm, 2002

[2] FEKETE, M.: Manažment kvality. Bratislava: UK, 2002

[3] GAŠPARÍK, J.: Manažérstvo kvality v stavebníctve. Bratislava: Jaga Group, 2002

[4] HAMMER, M. - CHAMPY, J.: Reengineering - radikální proměna firmy. Praha: Management Press, 1996

[5] KMEŤ, S. - MAGNER, P.: Fast way to quality. Communications on the edge of the millenniums $-10^{\text {th }}$ international scientific conference. Žilina, 1998

[6] LEGE, R.: Bussines process a total quality management. In: Kvalita 1/2001

[7] LEŠČIŠIN, M. - MACKO, J.: Manažment kvality. Bratislava: EU, 1994

[8] MATEIDES a kol.: Manažérstvo kvality. Bratislava: Mračko, 2006

[9] MOLNÁR, P. - DUPAL, A.: Manažment inovácií podniku - manažment výrobkových inovácií v podniku. Bratislava: Ekonóm, 2002

[10] MOLNÁR, P. - SVATÝ, F. - MACKO, J. - KAPUSTA, J.: Manažment kvality zbierka príkladov. Bratislava: Ekonóm, 2000

[11] NENADÁL, J.: Měrení v systémech managementu jakosti. Praha: Management Press, 2001

[12] NENADÁL, J. - NOSKIEVIČOVÁ, D. - PETŘÍKOVÁ, R. - PLURA, J.: Moderní systémy ř́zení jakosti. Praha: Management Press, 1998

[13] PLURA, J.: Plánování a neustále zlepšování jakosti. Praha: Computer Press, 2001 
[14] ŠMÍDA, F.: Zavádení a rozvoj procesního řizení ve firme. Praha: Grada Publishing, 2007

[15] TOMEK, G. - VÁVROVÁ, V.: Řizení výroby. Praha, 1999

[16] VANČÍKOVÁ, Z.: Výber nástrojov a metód zlepšovania kvality. Banská Bystrica: Ekonomická fakulta UMB - OZE, 2001

[17] VEBER, J. a kol.: Ǩizení jakosti a ochrana spotřebitele. Praha: Grada Publishing, 2002

[18] WARNECKE, J., H. a kol.: Niektoré prístupy k zlepšovaniu procesov: Ako systematicky zlepšovat' procesy v podnikoch - fraktálový podnik. In: Kvalita 3/2000

\section{Grantová podpora}

Príspevok vznikol na základe doktorandskej dizertačnej práce a riešenia výskumných projektov VEGA 1/4573/07 Možnosti, ohraničenia a vývojové tendencie koncepcie univerzálnej služby $v$ pošte a telekomunikáciách $v$ procese globalizácie a MVTS Nem/SR/ŽU3/07 Aplikácia cyklu PDCA v službách ako faktor zvyšovania efektívnosti riadenia kvality. 